\title{
PENERAPAN WAKTU KERJA LEMBUR MENURUT UU NO. 13 TAHUN 2003 TENTANG TENAGA KERJA PADA LULUSAN BARU JURUSAN TEKNIK SIPIL POLITEKNIK NEGERI JAKARTA YANG BEKERJA DI PERUSAHAAN KONSTRUKSI Rita Farida ${ }^{1)}$ dan Dyah Nurwidyaningrum \\ Jurusan Teknik Sipil Politeknik Negeri Jakarta \\ Email: ${ }^{1}$ r.farida@rocketmail.com
}

\begin{abstract}
Every Company has to implement a role of working hours based on Labor Regulation (UU No.13/2003). If a labor works morethan working time limit than the Company has to pay working overtime. This 3 hours overtime only implemented in a workday or 14 hours in a week. Kepmen. No. 233/MEN/2003 determines that an employer can work overtime of the role (UU No.13/2003), depends on charactheristic of work. Working on Construction needs long hours, caused some works cannot be delayed. It can impact to the demise of the production process and material damage. Fresfgraduates of civil engineering, Politeknik Negeri Jakarta, that work on construction company are generally lack of knowledge and working expperience, if company does them for working not in worktime, no shifting, no working overtime, may cause K3 problem. This research is done to analyze freshgraduates work overtime and payment which suits regulation. The research objection is to discover new recommendation ideas that benefit the Jakarta State Polytechnic, especially the final semester students. This result can be used to as information before entering work. Then, researcher can find idea of thinking how the labor rules and uses it for freshgraduate preparation.
\end{abstract}

Keywords: Implementation of work overtime, labor regulation No. 13/2013, freshgraduate, construction company.

\section{Abstrak}

Setiap pengusaha wajib melaksanakan ketentuan jam kerja sesuai UU Ketenagakerjaan No.13 tahun 2003. Apabila melebihi ketentuan waktu kerja tersebut, maka waktu kerja dianggap lembur sehingga pekerja berhak atas upah lembur. Lembur hanya diperbolehkan tidak lebih dari 3 (tiga) jam dalam 1 (satu) kerja, dan 14 (empatbelas) jam dalam 1 (satu) minggu. Kepmen. No. 233/MEN/2003 membolehkan karyawannya bekerja melebihi ketentuan UU No. 13 tahun 2003, asal saja pekerjaan yang dilakukan menurut jenis dan sifatnya harus dilaksanakan atau dijalankan secara terus menerus. Pekerjaan dalam bidang konstruksi memerlukan waktu panjang, mengingat beberapa pekerjaan apabila ditunda mengakibatkan terhentinya proses produksi dan rusaknya bahan. Lulusan baru Jurusan Teknik Sipil Politeknik Negeri Jakarta yang bekerja di perusahaan konstruksi kurang memiliki pengetahuan dan pengalaman bekerja, apabila perusahaan konstruksi mempekerjakan lulusan tidak sesuai jam kerja, tidak ada shift, tidak ada kompensasi lembur akan menimbulkan masalah terhadap K3. Penelitian meneliti penerapan jam kerja dan pengupahan yang sesuai ketentuan peraturan perundang-undangan, terhadap lulusan baru. Diharapkan melalui penelitian ini ditemukan gagasan baru/rekomendasi pemikiran yang bermanfaat bagi Politeknik Negeri Jakarta, khususnya mahasiswa semester akhir, dimana hasil penelitian dapat digunakan sebagai indikator sebelum memasuki dunia kerja, agar ditemukan gagasan pemikiran bagaimana aturan tentang ketenagakerjaan lebih berperan untuk lulusan dalam memasuki lapangan kerja.

Kata Kunci: penerapan waktu kerja lembur, UU No 13 Tahun 2013 tentang Tenaga Kerja, lulusan baru, perusahaan konstruksi 


\section{PENDAHULUAN}

\section{Latar Belakang}

Undang-Undang Nomor 13 Tahun 2003

Tentang Ketenagakerjaan mewajibkan setiap pengusaha melaksanakan ketentuan jam/waktu kerja, akan tetapi, ketentuan jam/waktu tidak berlaku bagi sektor usaha atau pekerjaan tertentu. Pekerjaanpekerjaan tertentu yang harus dijalankan terus menerus seperti diatur oleh Keputusan Menteri Tenaga Kerja dan Transmigrasi (Kepmennakertrans) Nomor Kep-233/Men/2003 Tahun 2003 tentang Jenis dan sifat pekerjaan yang dijalankan secara terus menerus ini dilakukan dengan pembagian waktu kerja ke dalam penggantian pekerjaan/shift.

Dalam praktek ketentuan-ketentuan tersebut dilanggar, khususnya dalam bidang pekerjaan konstruksi, waktu yang mendesak karena bangunan harus selesai sesuai target kontrak, mengakibatkan pekerja didalam melakukan pekerjaan konstruksi tidak dibatasi waktu, atau bekerja tidak sesuai ketentuan jam/waktu kerja yang berlaku baik sesuai UU Ketenagakerjaan maupun, Kepmenakertrans.

Sesuai bidang ilmu yang dikuasai lulusan baru Jurusan Teknik Sipil Politeknik Negeri Jakarta sebagian besar bekerja di perusahaan konstruksi. Lulusan baru yang tidak memiliki banyak pengetahuan dan masih memerlukan pengalaman bekerja mungkin menjadi sasaran bagi pelanggaran ketentuan jam/waktu kerja. Bekerja tanpa batas waktu, tidak ada shift, tidak ada kompensasi lembur dan apabila terjadi merupakan pelanggaran aturan dan menimbulkan masalah baik terhadap kesehatan maupun keselamatan kerja.

\section{Masalah}

Permasalahan yang timbul adalah:

a) Apakah peraturan perundang-undangan yang ada, secara jelas mengatur jam kerja khusus di perusahaan di bidang konstruksi b) Apakah masalah-masalah yang timbul akibat dari tidak dibatasinya jam/waktu kerja di perusahaan konstruksi

c) Faktor-faktor dan hambatan-hambatan apa sajakah yang mempengaruhi proses penerapan pembatasan jam/waktu kerja seperti diatur dalam UU Tenaga Kerja Nomor 13 tahun 2003.

Hipotesa yang kami ajukan dalam penelitian ini adalah jika penerapan aturan pembatasan waktu kerja dilaksanakan dengan baik, kesehatan dan keselamatan mereka terjamin, mereka tidak mudan berpindah pindah pekerjaan.

\section{Tujuan}

Tujuan Utama yang dhendak dicapai dari penelitian ini adalah:

a) Memahami dan menggambarkan penerapan jam kerja sesuai peraturan perundang-undangan yang berlaku bagi lulusan baru Jurusan Teknik Sipil Politeknik Negeri Jakarta.

b) Memahami dan menggambarkan bentuk-bentuk pelanggaran aturan jam/waktu kerja

c) Memahami dan menggambarkan bagaimana respon lulusan baru tehadap pentingnya peranan aturan jam/waktu kerja sesuai peraturan perundangundangan bagi kesehatan dan keselamatan kerja mereka.

\section{Kontribusi Penelitian}

Diharapkan hasil penelitian ini dapat memberikan:

1. Sumbangan pemikiran pada pengembangan ilmu hukum. Khususnya, pengkajian penerapan jam/waktu kerja pada lulusan baru Jurusan Teknik Sipil Politeknik Negeri Jakarta

2. Memberikan manfaat praktis pembekalan pengaturan tentang ketentuan jam kerja, bagi lulusan baru Jurusan Teknik Sipil Politeknik Negeri Jakarta. 


\section{Tinjauan Pustaka}

\section{Teori-Teori Hukum}

Teori-teori hukum memiliki fungsi menjelaskan ketentuan-ketentuan yang berlaku, menilai perbuatan-perbuatan hukum, menganalisa permasalahanpermasahan dengan memperhatikan faktafakta dan filsafat hukum yang berkembang dengan tetap memperhatikan sifat dasar ataupun karakteristik khusus dari suatu hal yang diletakan sebagai objek kajiannya. Teori hukum juga bergelut dengan hubungan antara hukum dengan logika. Apakah berpikir yurudis atau penalaran yuridis adalah sesuatu yang berbeda dari berpikir atau penalaran biasa.

\section{Teori Keadilan Komutatif}

Prinsip keadilan komutatif menurut Adam Smith adalah tidak merugikan dan melukai orang lain baik sebagai manusia, anggota keluarga atau anggota masyarakat baik menyangkut pribadinya, miliknya atau reputasinya. Pertama, keadilan tidak hanya menyangkut pemulihan kerugian, tetapi juga menyangkut pencegahan terhadap pelanggaran hak dan kepentingan pihak lain. Kedua, pemerintah dan rakyat sama-sama mempunyai hak sesuai dengan status sosialnya yang tidak boleh dilanggar oleh kedua belah pihak.

\section{Metode Penyempitan/Pengkongkritan Hukum (Rechsvervijnings)}

Metode ini bertujuan mengkonkritkan / menyempitkan suatu aturan hukum yang terlalu abstrak, luas dan umum. Agar dapat diterapkan dalam suatu peristiwa tertentu.

\section{Teori Utilitarisme}

Menrut teori ini, suatu perbuatan adalah baik jika membawa manfaat, berfaedah atau berguna. Manfaat bukan saja bagi bagi satu atau dua orang namun bagi masyarakat sebagai keseluruhan.

\section{Kerangka Konseptual}

Menurut Makarim yang dimaksud konsep adalah pemaparan pemikiran yang akan memperlihatkan beberapa faktor kunci atau variable dalam penelitian.

\section{Konsep jam kerja/waktu kerja menurut UU No. 13 Tahun 2003 tentang Ketenagakerjaan}

Pasal 77 (2) waktu kerja meliputi 7 (tujuh) jam kerja dalam 1 (satu) hari atau 40 (empatpuluh) jam kerja dalam 1 (satu) minggu untuk 6 (enam) hari kerja dalam 1 (satu) minggu. 8 (delapan) jam kerja dalam 1 (satu) hari atai 40 (empatpuluh) jam kerja dalam 1 (satu) minggu untuk 5 (lima) hari kerja dalam 1 (satu) minggu. Pasal 77 (3) Ketentuan jam/ waktu kerja sebagaimana dimaksud dalam ayat (2) tidak berlaku bagi sektor usaha atau pekerjaan tertentu. Pasal 77 ayat (4) ketentuan mengenai waktu kerja pada sektor usaha atau pekerjaan tertentu sebagaimana dimaksud dalam ayat (3) diatur dengan Keputusan Menteri.

Pasal 78 ayat (1) mengatakan bahwa, Pengusaha yang mempekerjakan pekerja/buruh melebihi waktu kerja, harus memenuhi syarat: a. ada persetujuan pekerja/buruh yang bersangkutan; b. waktu kerja lembur hanya dapat dilakukan paling banyak 3 (tiga) jam dalam satu hari dan 14 (empatbelas) jam dalam 1 (satu) minggu. Pasa; 78 ayat (2) Pengusaha yang mempekerjakan pekerja/buruh melebihi waktu kerja sebagaimana dimaksud dalam ayat (1) huruf b tidak berlaku bagi sektor usaha atau pekerjaan tertentu. Pasal 78 ayat (4) Ketentuan mengenai waktu kerja lembur dan upah kerja lembur sebagaimana dimaksud dalam ayat (2) dan ayat (3) diatur dengan Keputusan Menteri.

\section{Konsep tidak adanya Diskriminasi bagi Tenaga Kerja}

Menurut Pasal 5 UU No. 13 tahun 2003 tentang Ketenagakerjaan mengatakan bahwa, "Setiap tenaga kerja memiliki kesempatan yang sama tanpa diskriminasi untuk memperoleh pekerjaan”, dan Pasal 6 mengatakan bahwa, "Setiap pekerja berhak memperoleh perlakuan yang sama tanpa diskriminasi dari pengusaha”. 


\section{Konsep Pengusaha dan Perusahaan Konstruksi}

Menurut Pasal 1 ayat (5) UU No. 13 tahun 2003, Pengusaha adalah: orang perorangan, persekutuan, atau badan hukum yang menjalankan suatu perusahaan milik sendiri. b. orang perorangan, persekutuan, atau badan hukum yang secara berdiri sendiri menjalankan suatu perusahaan bukan miliknya. c. orang perorangan, persekutuan, atau badan hukum yang berada di Indonesia mewakili perusahaan sebagaimana dimaksud huruf a, b yang berkedudukan di luar wilayah Indonesia.

\section{Konsep Kesehatan Keselamatan Kerja}

Kesehatan dan Keselamatan Kerja (K3) merupakan instrument memproteksi pekerja, perusahaan, lingkungan hidup, dan masyarakat sekitar dari bahaya akibat kecelakaan kerja. Perlindungan tersebut merupakan hak asasi yang wajib dipernuhi oleh perusahaan. K3 bertujuan mencegah, mengurangi, bahkan menihilkan risiko kecelakaan kerja.

\section{Luluan Baru Jurusan Teknin Sipil Politeknik Negeri Jakarta}

Lulusan baru adalah alumni yang baru saja meyelesaikan kuliah di Jurusan Teknik Sipil Politeknik Negeri Jakarta yang memiliki masa kerja mulai dari 0 tahun sampai 3 tahun dan bekerja di perusahaan konstruksi.

\section{METODE PENELITIAN}

\section{Tempat Penelitian}

Peneliti menjadikan wilaya Kota Jabodetabek (Jakarta Bogor Depok Bekasi) sebagai tempat penelitian.

\section{Objek Penelitian}

Peneliti menjadikan lulusan baru sebagai objek penelitian. Lulusan baru adalah semua mahasiswa Jurusan Teknik Sipil Politeknik Negeri Jakarta dengan Program Studi Teknik Konstruksi Gedung,
Teknik Kontruksi Sipil, Jalan Tol, Jalan dan Jempabatan, Manajemen Kontruksi. Lulusan baru tersebut yang berhasil menyelesaikan pendidikannya pada tahun 2012, 2013, 2014 dan yang memiliki masa kerja di bidang konstruksi mulai dari 0 (nol) tahun sampai 3 (tiga) tahun.

\section{Metode Pendekatan}

Peneliti menggunakan metode pendekatan normative empiris, dimana metode pendekatan ini dilakukan dengan mengumpulkan data tidak saja di kepustakaan tetapi juga dii lapangan dan penellitian lapangan dalam hal ini berkomunikasi dengan lulusan baru Jurusan Teknik Sipil Politeknik Negeri Jakarta dan pihak-pihak yang peneliti anggap mewakili perusahaan konstruksi tempat lulusan baru bekerja. Pendekatan penelitian dapat juga disebut normative sosiologis atau juridis soliologis, mengingat permasalah yang diterliti mengenai hubungan antara factor sosiologis terhadap factor yuridis.

\section{Metode Penelitian}

Peneliti didalam mendekati pokok masalah penelitian, digunakan penelitian eksplanatoris, suatu penelitian yang berusaha menerangkan, memperkuat atau menguji dan bahkan menolak suatu teori atau hipotesa-hipotesa serta terhadap hasilhasil penelitian yang ada atau kerakteristik dari suatu gejala social yang diteliti dan sejumlah faktor yang mempengaruhinya.

\section{Metode Pengumpulan Data}

Metode pengumpulan data dengan cara penelitian lapangan, langsung pada objekobjek penelitian yang ada hubungannya dengan masalah yang diteliti. Sedangkan teknik pengumpulan data dilakukan dengan dua cara yaitu wawancara (interview) dan angket/kuisioner

\section{Metode Analisa Data (Analisa}

Pendahuluan, dan Analisa Uji Hipotesa)

Metode analisa data dengan cara pengumpulan data dan dianalisa melalui 
dua tahap: pertama, analisa pendahuluan yang bermaksud mendeskripsikan karakteristik sampel pada setiap variable yang diteliti. Kedua analisa uji hipotesa, yang bermaksud untuk menguji benar tidaknya hipotesa yang telah disusun. Teknik analisa uji hipotesa yang dipergunakan akan ditentukan kemudian berdasarkan tipe data yang dikumpulkan.

\section{HASIL DAN PEMBAHASAN Ketentuan Jam Kerja/Waktu Kerja lembur di Bidang Konstrusi}

Aturan jam kerja/waktu kerja seperti diatur pasal 77 ayat (2) tidak berlaku bagi sektor usaha tertentu atau pekerjaan tertentu (pasal 77 ayat 3). Ketentuan waktu kerja sebagaimana dimaksud dalam ayat (3) diatur dalam Kepmentransker Nomor Kep. 233/MEN/2003 tentang Jenis dan Sifat Pekerjaan yang dijalankan secara terus menerus. Dalam Kepmentransker dimaksud pasal 1 ayat (1), Pekerjaan yang dijalankan secara terus menerus adalah pekerjaan yang menurut jenis dan sifatnya harus dilaksanakan atau dijalankan secara terus menerus atau dalam keadaan lain berdasarkan kesepakatan antara pekerja/buruh dengan pengusaha. Pasal 2, Pengusaha dapat mempekerjakan pekerja/buruh pada hari libur resmi untuk pekerjaan yang menurut sifat harus dilaksanakan dan dijalankan dan dijalankan secara terus menerus. Pasal 3 ayat (1), Pekerjaan sebagaimana dimaksud dalam Pasal 2 seperti salah satunya disebutkan dalam point $\mathrm{f}$, yaitu jenis pekerjaan yang apabila dihentikan akan menggannggu proses produksi, merusak bahan dan termasuk pemeliharaannya / perbaikan produksi

Pekerjaan konstruksi, sangat sulit untuk tidak melakukan lembur terutama saat pengecoran, karena jika berhenti maka akan mengganggu proses produksi. Dengan demikian bidang kontrusi termasuk pekerjaan yang karyawannya diijinkan untuk melakukan pekerjaan di luar batas jam (melebihi batas tiga jam waktu yang diperbolehkan lembur).
Di PT. Murinda Iron Steel untuk pekerjaan yang biasa, jam kerja/waktu kerja lembur tidak semua karyawan mendapatkannya, kecuali site engineer, administrasi, dokumen control dan project manajer. Sedangkan yang bekerja sampai 7 (tujuh) hari mandor dan tukang yang diawasi staff yang mendapat giliran piket, kecuali untuk pengecoran skala besar MAT Found atau MASS concrete yang melakukan piket dari semuanya bagian tanpa terkecuali dengan demikian disini terjadi lembur.

Dari hasil wawancara dibuktikan bahwa pekerjaan bidang konstrusi termasuk kedalam pekerjaan dimaksud dalam aturan Kepmentrans. No. 233/MEN/2003 pasal 1 ayat (1), pekerjaan yang dijalankan secara terus menerus adalah pekerjaan menurut jenis dan sifatnya harus dilaksanakan atau dijalankan secara terus menerus dalam keadaan lain berdasarkan kesepakatan antara pekerja/buruh dengan pengusaha. Pasal 2, pengusaha dapat mempekerjakan pekerja/buruh pada hari libur resmi untuk pekerjaan yang menurut sifat jenis nya harus dijalankan secara terus menerus. Pasal 3 ayat (1), pekerjaan sebagaimana dimaksud, yaitu "Pekerjaan yang apabila dihentikan akan mengganggu proses produksi, merusak bahan, dan termasuk pemeliharannya/perbaikan produksi .

\section{Ketentuan Tentang Upah Lembur}

Keputusan Menteri Tenaga Kerja dan Transmigrasi Republik Indonesia No. Kep. 102/MEN/VI/2004 tentang Waktu Kerja Lembur dan Upah Kerja Lembur. Pasal 2 ayat (1) pengaturan kerja lembur berlaku untuk semua perusahaan, kecuali bagi perusahaan sector usaha tertentu atau pekerjaan tetentu sebagaimana dimaksud dalam ayat (1) diatur tersendiri dengan Keputusan Menteri. Pasal 3 ayat (2) menyebutkan, ketentuan waktu kerja lebur sebagaimana dimakskud dalam ayat (1) tidak termasuk kerja lembur yang dilakukan pada waktu istirahat mingguan atau hari libur resmi. Pasal 4 ayat (1) Pengusaha yang mempekerjakan 
pekerja/buruh melebihi waktu kerja, wajib membayar upah lembur. Pasal 4 ayat (2) bagi pekerja/buruh yang termasuk dalam golongan jabatan tertentu, tidak berhak atas upah kerja lembur sebagaimana dimaksud dalam ayat (1), dengan ketentuan mendapat upah yang lebih tinggi. Pasal 4 ayat (3) yang termasuk dalam golongan jabatan tertentu sebagaimana dimaksud dalam ayat (2) adalah mereka yang memiliki tanggungjawab sebagai pemikir, perencana, pelaksana dan pengendali jalannya perusahaan yang waktu kerjanya tidak dapat dibatasi menurut waktu kerjayang ditetapkan perusahaan sesuai dengan peraturan perundang-undangan yang berlaku. Pasal 5, perhitungan upah kerja lembur berlaku bagi semua perusahaan, kecuali bagi perusahaan pada sector usaha tertentu atau pekerjaan tertentu sebagaimana dimaksud Pasal 2. Pasal 8 ayat (1) Perhitungan upah lembur didasarkan pada upah bulanan. Pasal ayat (2) cara menghitung upah sejam adalah 1/173 kali upah sebulan.

Karyawan PT. Murinda Iron Steel, melakukan kerja lembur karena dipaksa lembur dan memaksakan lembur agar mendapatkan upah lembur. Di perusaahan ini hanya golongan II kebawah yang mendapat uang lembur dan uang makan. Lembur bisa sampai pagi, jika sampai pagi keesokan harinya libur. Uang lembur dibatasi maksimal 1 (satu) juta per 1 (satu) bulan. Kantor PT. Murinda Iron Steel mensosialisasikan aturan lembur, waktu kerja, upah dan lain-lain pada saat tandatangan kontrak (sesuai Kep. Men 102/MEN/VI/2004). PT. Multikon memiliki kebijakan semua golongan mendapatkan uang intensive/lembur dan uang makan lembur.

\section{Penerapan Aturan Jam Kerja/Waktu Kerja, Upah Lembur, Keselamatan dan Kesehatan Kerja bagi Lulusan Baru Jurusan Teknik Sipil Politeknik Negeri Jakarta.}

Tabel 1. Prosentase alumni Jurusan Teknik Sipil yang menjadi sampel

\begin{tabular}{lcl}
\hline Jawab & Jumlah & Presentase \% \\
\hline a. Angkatan 2007 & 7 & 7,61 \\
b. Angkatan 2008 & 18 & 19,57 \\
c. Angkatan 2009 & 15 & 16,30 \\
d. Angkatan 2010 & 35 & 38,04 \\
e. Angkatan 2011 & 17 & 18,485 \\
\hline
\end{tabular}

Dari table dapat dilihat bahwa lulusan yang berasal dari angkatan 2010 yang paling antusias mengembalikan dan mengisi kuisioner 38,04\% sedangkan yang paling sedikit dari angkatan 2007 yaitu $7,61 \%$

Tabel 2. Lulusan baru mengetahui aturan jam kerja UU Tenaga Kerja No.13 tahun2003

\begin{tabular}{lll}
\hline $\begin{array}{l}\text { Mengetahui jam } \\
\text { kerja }\end{array}$ & Jumlah & Presentase \% \\
\hline $\begin{array}{lll}\text { a.mengetahui } & 62 & 67,40 \\
\text { b.tidak mengetahui } & 30 & 32,60\end{array}$
\end{tabular}

Lulusan baru lebih banyak yang mengetahui tentang aturan jam kerja daripada yang tidak mengetahui, yang mengetahui $67,40 \%$ sedangkan sisanya tidak mengetahui. Mengapa demikian dapat dimengerti karena dari dosen mata kuliah K3 dan Hukum Ketenagakerjaan, aturan ini di informasikan kepada mahasiswa, selain lulusan baru mengetahui aturan ini dari kontrak kerja yang mereka tandatangani

Table 3. Kelebihan jam kerja rata-rata setiap minggu

\begin{tabular}{clll}
\hline \multicolumn{2}{l}{ Kelebihan jam kerja } & jumlah & Presentase $\%$ \\
\hline a. & $<3$ jam & 32 & 34,78 \\
b. $\quad>3$ jam & 35 & 38,04 \\
c. $\quad>6$ jam & 9 & 9,78 \\
d. $\quad>10$ jam & 11 & 11,96 \\
e. & $>14$ jam & 5 & 5,43 \\
\hline
\end{tabular}

Lulusan baru yang bekerja lembur kurang dari 3 (tiga) jam berjumlah 38,04\%. Dari data diatas juga dapat dilihat bahwa responden yang bekerja lembur sampai 14 (empatbelas) jam hanya 5,43\% 
Table 4. Lembur melebihi jam kerja

\begin{tabular}{|c|c|c|}
\hline Jawab & Jumlah & Presentase \\
\hline $\begin{array}{l}\text { a. lembur melebihi } \\
\text { jam kerja }\end{array}$ & 55 & $59,78 \%$ \\
\hline $\begin{array}{l}\text { b. lembur tidak } \\
\text { melebihi jam kerja }\end{array}$ & 37 & $40,22 \%$ \\
\hline
\end{tabular}

Dari data diatas, dapat dilihat bahwa lulusan baru yang bekerja melebihi jam kerja adalah 59,78 \%

Table 5. Lembur dan kesehatan fisik

\begin{tabular}{lll}
\hline Jawab & Jumlah & $\begin{array}{l}\text { Presentase } \\
\%\end{array}$ \\
\hline a. Sangat setuju & 21 & 22,83 \\
b. Setuju & 34 & 36,96 \\
c. Biasa saja & 30 & 32,61 \\
d. Tidak setuju & 7 & 7,61 \\
\hline
\end{tabular}

Dari table diatas diketahui bahwa diberlakukannya lembur tidak mengganggu kesehatan fisik sebanyak $7,61 \%$ sedangkan yang sangat setuju bahwa lembur mengganggu kesehatan fisik sebanyak $36,96 \%$

Table 6. Lembur menimbulkan gangguan psikis

\begin{tabular}{lll}
\hline Jawab & Jumlah & $\begin{array}{l}\text { Presentase } \\
\%\end{array}$ \\
\hline a.stress & 30 & 32,61 \\
b.tertekan & 13 & 14,13 \\
c.marah, jengkel & 13 & 14,13 \\
d.protes & 17 & 18,48 \\
A,b,c da d benar & 19 & 20,65 \\
\hline
\end{tabular}

Kombinasi jawaban stress, tertekan, marah, jengkel, protes sebanyak 20,65\% dari responden tidak memilih semua gangguan psikis tersebut, namun kombinasi diantaranya, dan yang paling banyak dialami oleh responden adalah stress $32,61 \%$

Table 7. Mengalami gangguan keselamatan kerja

\begin{tabular}{lll}
\hline Jawab & Jumlah & $\begin{array}{l}\text { Presentase } \\
\%\end{array}$ \\
\hline a.ya & 30 & 32,61 \\
b.tidak & 62 & 67,39 \\
\hline
\end{tabular}

Sedikit jumlah responden yang pernah mengalami terganggunya keselamatan kerja 32,61\% lainnya tidak pernah mengalami $67,39 \%$

\section{Pengetahuan Ketentuan Lembur dan Upah Lembur bagi Lulusan Baru}

Sebagian besar responden kurang mengetahui ketentuan upah lembur hanya 53,26 \%, meskipun pengetahuan tentang upah lembur sesuai Kep men sudah di berikan pengetahuannya oleh dosen sewaktu lulusan baru kuliah. Sebenarnya kewajiban dari perusahaan untuk mensosialisasikan pengetahuan tentang aturan lembur pada saat tanda tangan kontrak. Kontrak biasanya dilengkapi lampiran rincian pendapatan, gaji pokok, tunjangan proyek, tunjangan jabatan, uang makan harian, uang transport, intensive lembur, waktu kerja, upah, dll.

\section{KESIMPULAN DAN SARAN Kesimpulan}

Ketentuan bagi jam/waktu kerja, lembur, upah lembur, keselamatan dan kesehatan kerja bidang konstruksi aturan yang berlaku sebagai berikut: UU No. 13 tahun 2003 tentang Ketenagakerjaan, pasal 77 sampai dengan pasal 85 mengatur tentang jam/waktu kerja. Pasal 86 ayat (1) mengatur tentang keselamatan dan kesehatan kerja. Kep. Men. Tenaga Kerja dan Transmigrasi Republik Indonesia No. Kep. 233/MEN/2003 tentang jenis dan sifat Pekerjaan yang dijalankan secara terus menerus, pasal 1 ayat (1) huruf $k$, mengatur ketentuan upah dan lembur. Kep. Men. Tenaga Kerja dan Transmigrasi Republik Indonesia No. Kep. 102/MEN/VI/2004 tentang Waktu Kerja Lembur dan Upah Kerja Lembur, pasal 2,3,4 dan 8. Terdapat masalah-masalah yang timbul akibat dari tidak dibatasinya jam kerja di perusahaan konstruksi, namun masalah ini tidak menjadi signifikan mengingat bagi lulusan baru jam/waktu kerja lembur masih dalam batas toleransi. Adapun factor-faktor dan hambatanhambatan yang mempengaruhi proses penerapan pembatasan jam kerja seperti diatur dalam UU Tenaga Kerja no. 13 tahun 2003, terjadi terutama saat dilakukan pengecoran dalam skala besar namun ini 
dibatasi oleh ketentuan libur keesokan harinya setelah bekerja 1 (satu) hari 1 (satu) malam dan ini terhitung no rest artinya tidak berlaku azas no work no pay dalam keadaan ini.

\section{Saran}

Mengingat dari data kuisioner yang didapatkan menginformasikan bahwa masih banyak terdapat lulusan baru yang bekerja di bidang konstruksi tidak memahami ketentuan jam/waktu kerja, upah, dan upah lembur, keselamatan dan kesehatan kerja. Sebaliknya dosen-dosen yang mengajarkan mata kuliah yang memasukan topic tentang keselamatan kesehatan kerja dan hokum ketenagakerjaan lebih intensif lagi memberi informasi tentang jam/waktu kerja, upah, dan upah lembur berikur peraturan perundang-undangannya.

\section{DAFTAR PUSTAKA}

Goa, Hillon, Dunia Konstruksi Indonesia, http://pengamatkonstruksiindonesia.blogspot/diunggah tanggal 3 Maret 2014

Indonesia, Undang-Undang Tentang Jasa Konstruksi, UU No. 18 Tahun 1999

Indonesia, Undang-Undang Tentang Ketenagakerjaan, UU No. 13 Tahun 1999

Indonesia, Keputusan Menteri Tenaga Kerja dan Transmigrasi Republik Indonesia Tentang Waktu Kerja Lembur dan Upah Kerja Lembur No. Kep. 102/MEN/VI/2004 Fokus Media Bandung, 2014

Indonesia, Keputusan Menteri Tenaga Kerja dan Transmigrasi Republik Indonesia Tentang Jenis dan Sifat Pekerjaan yang dijalankan secara terus menerus No. Kep. Men. 233/MEN/2003. Fokus Media Bandung, 2014
Hanitiyo, Ronny. Metodelogi Penelitian Hukum. Ghalia Indonesia Jakarta, 1983

Manulang, Senjun. Pokok-Pokok Hukum Ketenagakerjaan di Indonesia, Rhineka Cipta, Jakarta, 1983

Yasin, Nazarkan, Mengenal Kontrak Konstruksi di Indonesia, Jakarta: PT.Gramedia Pustaka Utama, 2003 